\title{
Konsistensi Kebijakan Polandia terhadap Sanksi Uni Eropa terhadap Rusia pada tahun 2014
}

\author{
Vanada Hanindita Anjani \\ Universitas Airlangga
}

\begin{abstract}
Abstrak
Sejak terjadinya krisis di Ukraina pada tahun 2014, keamanan kawasan Eropa Timur terganggu oleh ancaman Rusia. Sanksi ekonomi telah diterapkan oleh Uni Eropa kepada Rusia. Namun sanksi tersebut tidak membuat Rusia mundur dari kebijakannya menganeksasi Krimea, dan pada tahun yang sama Rusia memberlakukan embargo terhadap produk pangan Uni Eropa dan negara Barat. Embargo tersebut mengakibatkan kerugian pada negara-negara Uni Eropa yang menjalin kerjasama ekspor pangan dengan Rusia. Polandia mengalami kerugian pada sektor agrikulturnya akibat embargo tersebut. Selain itu potongan suplai gas dari Rusia juga turut mengganggu kondisi ekonomi Polandia. Akibat embargo tersebut negara-negara Uni Eropa perlahan menunjukkan adanya pergeseran terhadap dukungan sanksi ekonomi kepada Rusia. Fokus penelitian ini adalah alasan Polandia tetap mendukung sanksi meskipun mengalami kerugian akibat embargo.
\end{abstract}

Kata-kata Kunci: Polandia, Rusia, Krisis Ukraina, Eropa Timur, Sanksi Ekonomi, Embargo Rusia, Kebijakan Luar Negeri.

Since Ukraine crisis in 2014, security of East Europe threatened by Russia. Economic sanction was imposed by European Union. But the economic sanction doesnt make Russia stop from their foreign policy to annexationing Crimea, and at the same time Russia imposing an embargo to West and European Union countries member food products. Those embargo gives bad effect on economic relations between Russia and European Union countries member. Poland agriculture affected by Russia embargo. Russia cut energy supply to Poland that cause Poland economic worsen. Because of the embargo, some of European Union countries member shows opposite response to not support European Union sanction againts Russia. This research focus on the reason of why Poland choose to support European Union sanction even though their economic worsen because of embargo.

Keywords: Poland, Russia, Ukraine Crisis, East Europe, Economic Sanctions, Russia Embargo, Foreign Policy. 
Konflik yang terjadi antara negara-negara Uni Eropa dengan Rusia hingga penjatuhan sanksi diawali dengan peristiwa krisis di Ukraina. Krisis Ukraina dalam konteks ini mengarah pada krisis yang terjadi pada tahun 2014, ketika Rusia menganeksasi wilayah Krimea (BBC News, 2016). Peringatan dan pencegahan yang dilakukan Uni Eropa tidak membuahkan hasil, maka langkah selanjutnya adalah dengan sanksi. Sanksi yang dijatuhkan pada Rusia berupa sanksi ekonomi dan embargo perdagangan, diantaranya:

"(1) limit access to EU primary and secondary capital markets for 5 major Russian majority state-owned financial institutions and their majority-owned subsidiaries established outside of the EU, as well as three major Russian energy and three defence companies; (2) impose an export and import ban on trade in arms; (3) establish an export ban for dual-use goods for military use or military end users in Russia; and (4) curtail Russian access to certain sensitive technologies and services that can be used for oil production and exploration. (European Council, 2014)"

Penjatuhan sanksi terhadap Rusia diumumkan pada Maret 2014, dan direncanakan untuk berakhir pada Juli 2014. Namun rupanya pada Juli 2014, Rusia melakukan tindakan pembalasan terhadap sanksi Uni Eropa dengan mengembargo impor makanan dari negara-negara barat yang memberi sanksi termasuk Uni Eropa. Rusia pun tidak menarik pasukannya dari wilayah Krimea dan tetap melakukan aneksasi. Akhirnya Uni Eropa memutuskan untuk memperpanjang sanksi terhadap Rusia ini hingga September 2014. Perpanjangan sanksi terhadap Rusia berlanjut hingga enam bulan kedepan, tepatnya hingga Maret 2015. Pada Maret 2015 Uni Eropa memutuskan untuk memperpanjang sanksi hingga Juli 2016. Namun perpanjangan sanksi ini tetap tidak membuat Rusia mengubah keputusannya. Rusia tetap melakukan aneksasi terhadap wilayah Krimea dan juga memperpanjang embargo terhadap Uni Eropa. Menindaklanjuti sikap Rusia tersebut Uni Eropa akhirnya memperpanjang sanksinya hingga Juli 2017 (European Council, 2014). Pada Juni 2016, Rusia juga melakukan perpanjangan embargonya terhadap Uni Eropa hingga akhir 2017 (Kraatz 2014).

Akibat adanya sanksi ekonomi serta balasan embargo dari Rusia, dampaknya tidak hanya dirasakan oleh Rusia namun juga negaranegaraUniEropayangjuga masih bergantung denganRusia. Diantara negara-negara Uni Eropa yang terkena dampak embargo, Polandia 
mengalami kerugian yang cukup signifikan. Hal ini disebabkan, Rusia merupakan salah satu pasar terbesar bagi komoditas Polandia. Polandia memiliki komoditas agrikultur yang besar, dan apel Polandia adalah merupakan komoditas pangan terbesarnya. Akibat dari embargo Rusia tersebut, Polandia mengalami kerugian pada sektor agrikulturnya sebesar 500 juta Euro pada tahun 2014 (Kraatz 2014). Selain itu, ketergantungan Polandia terhadap suplai energi dari Rusia juga cukup besar. Produksi gas domestik sangat rendah yaitu hanya 28,2 persen, sehingga membutuhkan pasokan gas dari negara lain. Sebesar 75,9 persen gas Polandia diimpor dari Rusia, 19,9 persen dari Jerman, 3,5 persen dari Ceko, dan 0,7 persen dari Norwegia. Selain gas, Polandia juga mengimpor sebagian besar kebutuhan minyaknya dari Rusia, mencapai 97 persen (The Financial Times 2014). Namun pasokan gas dan minyak Polandia menjadi terhambat akibat Polandia membantu pasokan energi ke Ukraina. Pada 2014 Ukraina dan Polandia melakukan perjanjian kerjasama reverse-flow gas. Perjanjian ini merupakan perjanjian untuk menyalurkan energi Polandia ke Ukraina sebesar 4 juta meter kubik perharinya (RT News 2014). Tetapi perjanjian ini rupanya mendatangkan dampak buruk bagi Polandia. Pada September 2014 Rusia memotong pasokan gas ke Polandia sebesar 20 sampai 24 persen. Pengurangan jumlah pasokan gas ke Polandia ini dilakukan agar Polandia tidak bisa memberikan bantuan ke Ukraina. Dampak yang ditimbulkan dari embargo Rusia pun mempengaruhi angka pengangguran di Polandia. Sebanyak 23.000 pekerja Polandia kehilangan pekerjaannya akibat embargo Rusia (ING Group 2014). Menteri Ekonomi Polandia Janusz Piechocinski, mengungkapkan bahwa Polandia mengalami kerugian sebesar 500 juta dolar pada tahun 2014. Janusz Piechocinski mengatakan bahwa perkembangan ekonomi Polandia bergantung pada bagaimana kondisi krisis di Eropa Timur (Radio Poland 2014).

Meskipun demikian, Polandia tidak menarik diri dari dukungan sanksi terhadap Rusia. Dukungan Polandia terhadap sanksi ditunjukkan oleh Menteri Luar Negeri Polandia tahun 2015, Grzegorz Schetyna yang menyatakan bahwa mendukung sanksi Uni Eropa terhadap Rusia sampai enam bulan kedepan, tepatnya hingga Maret 2016. Menurut Schetyna, "But this (sanctions) is the only language Russia understands...Russia has helped all EU countries make the decision in a very determined and unambiguous way" (Radio Poland 2014). Selain Menteri itu Wakil Menteri Luar Negeri 
Polandia, Konrad Szymanski, menyatakan, “The European Union's authority ... in the future depends on the successful influencing Russia through sanctions"(Szary dan Sobczak 2016).

Namun sanksi yang dijatuhkan Uni Eropa ini perlahan-lahan mengalami keraguan dari negara anggotanya. Pada Januari 2016, Perancis menyatakan kesepakatan dari anggota parlemennya yang menginginkan sanksi terhadap Rusia dicabut. Disusul dengan pernyataan Presiden Perancis, Francois Hollande, bahwa sanksi ekonomi terhadap Rusia telah banyak merugikan negara-negara Uni Eropa dan menjadi penghambat terhadap proyek ekonomi Perancis (Press TV 2016). Menteri Luar Negeri Austria Sebastian Kurz juga menyatakan bahwa sanksi Uni Eropa sudah seharusnya secara bertahap mulai berkurang (Euractiv 2016). Jerman pun terbagi menjadi dua pendapat, dimana pihak pemerintahan Angela Merkel, mendukung keputusan Merkel untuk terus memperpanjang sanksi dan bertindak tegas terhadap Rusia. Sedangkan di sisi lain pihak Menteri Luar Negeri Jerman, Frank-Walter Steinmer, memimpin dukungan untuk melakukan pendekatan konsiliasi terhadap Rusia, menurutnya dengan semakin banyak tindakan atau pertemuan yang dilakukan NATO dan Uni Eropa maka akan semakin memprovokasi Rusia untuk melakukan agresi (Gotev 2016).

Selain melalui pernyataan, faktanya terdapat beberapa negara anggota Uni Eropa yang melakukan pelanggaran terhadap penerapan sanksi. Yunani, Spanyol dan Malta telah memberikan izin bagi kapal perang Rusia untuk berlabuh di negaranya untuk mengisi bahan bakar. Terutama Spanyol yang telah membantu pasukan angkatan laut Rusia dengan mengizinkan berlabuh sebanyak 22 kali (Coffey 2016). Pergeseran tidak hanya ditunjukkan oleh negaranegara di kawasan Eropa Barat, di Eropa Timur, Milo Zeman selaku Presiden Republik Ceko menginginkan hubungan yang dekat dengan Rusia, sehingga tidak menunjukkan sikap setuju terhadap sanksi Uni Eropa terhadap Rusia (Radio Free Europe 2015). Perdana Menteri Hungaria, Viktor Orban, menjelaskan bahwa Hungaria berada pada posisi yang netral. Hal tersebut dilatarbelakangi adanya ketergantungan terhadap energi Rusia dan tujuan Hungaria untuk mempererat hubungan kerjasama dengan Rusia (Sadecki, 2014). Pergeseran dukungan juga diungkapkan oleh Perdana Menteri Slovakia, Robert Fico, bahwa sanksi yang diterapkan kepada Rusia tidak dapat menyelesaikan konflik di Ukraina. Menurutnya, 
sanksi ekonomi ini telah memperburuk kondisi ekonomi negaranegara anggota Uni Eropa dan tidak berhasil mempengaruhi kebijakan agresif Rusia (Jancarikova dan Muller, 2016). Berdasarkan pemaparan latar belakang masalah diatas, menunjukkan bahwa terjadi pergeseran terhadap dukungan sanksi Uni Eropa kepada Rusia. Sedangkan Polandia tidak menunjukkan adanya perubahan keputusan untuk mendukung sanksi terhadap Rusia, meskipun embargo Rusia cukup mengakibatkan kondisi ekonomi Polandia memburuk. Kondisi ini kemudian menimbulkan pertanyaan, mengapa Polandia mendukung sanksi Uni Eropa terhadap Rusia, meskipun berakibat mengalami kerugian ekonomi? Untuk hal tersebut, penulis menggunakan teori penggunaan sanksi ekonomi sebagai instrument kebijakan luar negeri.

\section{Alasan Negara dalam mengambil Sanksi Ekonomi sebagai Instrumen Kebijakan Luar Negeri}

Ada tiga objectives yang akan disintesiskan di dalam tulisan ini, untuk menjelaskan alasan-alasan Polandia tetap mendukung kebijakan Uni Eropa. Pertama adalah teori penggunaan sanksi ekonomi sebagai instrumen kebijakan luar negeri. Sanksi ekonomi dipilih menjadi instrumen karena dapat mengurangi keterlibatan militer dalam penyelesaian suatu masalah. Hal ini dikarenakan sanksi berkerja dengan cara memberikan batasan dan tekanan terhadap negara target untuk merubah kebijakan. Tujuan dari pemberian sanksi adalah politik, yaitu merubah kebijakan atau sikap dari negara target, meskipun dalam penerapannya sanksi tidak langsung diterapkan pada sektor politik (Early 2016). Berdasarkan pada sikap negara yang memilih sanksi ekonomi sebagai alat diplomasi dengan tujuan merubah kebijakan suatu negara dapat dilihat melalui: (1) primary objectives, yang merupakan fokus negara terhadap tindakan dan sikap dari negara target; (2) secondary objectives, yang berhubungan dengan status, sikap dan ekspektasi dari pihak yang memberikan sanksi; (3) tertier objectives, yang berkaitan dengan pertimbangan terhadap kondisi lingkungan internasional atau dampak penerapan sanksi terhadap lingkungan internaisonal (Barber 1944). Ketiga hal tersebut akan menjelaskan alasan-alasan atau tujuan negara menggunakan sanksi terhadap suatu negara. 
Pertama, primary objectives atau alasan utama negara memilih sanksi sebagai instrumen. Dalam penggunaan sanksi ekonomi telah dijelaskan bahwa seringkali digunakan dalam konflik yang berhubungan dengan ekonomi maupun keamanan dan politik. Masalah keamanan menjadi primary objectives dapat dilihat dari paparan teori Barry Buzan mengenai regional security complex. Barry Buzan mengungkapkan bahwa security complex merupakan kondisi dimana negara-negara yang saling terhubung cukup erat antara satu sama lain sehingga keamanan masing-masing negara saling mempengaruhi (Buzan dan Waever 2003). Kondisi security complex ini digunakan untuk menjelaskan keamanan dalam level regional. Terdapat empat elemen penting dalam struktur regional security complex, yaitu:(1) perbatasan atau kondisigeografi; (2) strukturanarki; (3) polaritas atau arah kepentingan; (4) pola amity (persahabatan) dan enmity (permusuhan). Kemudian Barry Buzan menjelaskan adanya hubungan sistematis antara kondisi internal dan hubungan antara negara-negara dalam suatu regional, hubungan antar regional dan pengaruh dari dinamika regional dengan global power. Hal tersebut dijelaskan dalam empat peringkat analisis security constellation, yaitu: (1) secara domestik, negara dalam suatu regional memiliki tingkat kerentanan domestik terhadap stabilitas regional, yang mempengaruhi persepsi terhadap negara atau kelompok negara lain sebagai ancaman; (2) hubungan antar negara yang menjadi poin penting dalam pembentukan regional; (3) interaksi regional security complex dengan wilayah tetangga umumnya terbatas, karena fokus pada interaksi internal; (4) peran dari global power dalam suatu regional, menjelaskan hubungan antara struktur keamanan global dan regional (Buzan dan Waever 2003).

Kedua, secondary objectives negara yang mendukung alasan penggunaan sanksi dan dapat dilihat dari argumen milik Ades dan Chua yang menjelaskan adanya efek spillover akibat dari konflik keamanan yang mengarah pada kondisi ekonomi negara. Dalam tulisannya Ades dan Chua (1997) menjelaskan dua kondisi dimana regional instability akan berdampak pada kondisi ekonomi negara. Pertama adalah ketidakstabilan regional mengganggu arus perdagangan. Kedua, ketika ketidakstabilan regional menyebabkan meningkatnya biaya belanja militer karena untukmenjaga keamanan. Biaya pertahanan bagi negara-negara yang berada di wilayah konflik akan lebih besar (Ades dan Chua,1997). Regional instability pada dasarnya menjadi dasar pada lingkungan ekonomi yang 
menurun dan tidak pasti. Bagi negara-negara dalam satu kawasan yang memiliki kedekatan baik secara geografis maupun ekonomi maka kondisi keamanan regional menjadi penentu pertumbuhan ekonominya. Dalam tulisannya Ades dan Chua menjelaskan ketika terjadinya suatu perang baik dalam satu negara maupun antar negara maka masyarakat sipil yang menjadi korban akan berpindah mencari tempat perlindungan (Ades dan Chua,1997). Negara yang terlibat konflik tentu saja mengalami kerugian seperti kerusakan fasilitas negara dan meningkatnya kebutuhan di sektor keamanan yang membuat negara mengeluarkan biaya lebih. Namun dampak ini akan meluas ke negara tetangganya, karena menjadi tempat paling dekat dan aman bagi masyarakat yang butuh perlindungan. Hal ini menunjukkan bahwa konflik yang terjadi di satu negara akan memunculkan efek spillover yang merugikan negara tetangganya juga (Ades dan Chua,1997).

Berdasarkan kerangka pemikiran diatas, penulis memiliki dugaan bahwa alasan yang melatarbelakangi dukungan Polandia terhadap sanksi Uni Eropa kepada Rusia adalah sebagai primary objectives yaitu untuk mengembalikan keamanan di kawasan Eropa Timur karena turut mempengaruhi keamanan wilayah Polandia. Hal tersebut kemudian akan mempengaruhi secondary objectives mengenai kondisi ekonomi Polandia yang bergantung pada keamanan Eropa Timur.

\section{Pengaruh Regional Security Complex Eropa Timur Terhadap Keamanan Polandia}

Sejak berakhirnya Perang Dunia, negara-negara yang merupakan bagian dari Eropa Timur adalah Republik Demokrat Jerman, Polandia, Cekoslovakia, Hungaria, Yugoslavia, Albania, Bulgaria, dan Romania. Selain Yugoslavia dan Albania, negara dalam kawasan Eropa Timur tersebut merupakan blok dari Uni Soviet. Namun kondisi tersebut mulai berubah pada tahun 1989 dan 1991 ketika Uni Soviet mengalami kekalahan dalam Perang Dingin. Berubahnya kebijakan Uni Soviet yaitu glasnost dan perestroika membuat Uni Soviet menghentikan invasi militernya dan membuat negara-negara Eropa Timur melepaskan diri dari Uni Soviet. Kondisi di Eropa Timur mengalami perubahan dan mengalami konstruksi geografi baru yang disebut Post-socialist Europe (Dingsdale 1999). 
Selain itu kawasan Eropa Timur merupakan kawasan yang berada diantara negara-negara Eropa Barat dan Asia Tengah yang rawan konflik (Swiezak t.t.). Kondisi ini kemudian membuat Eropa Timur berpotensi menjadi pasar bagi bisnis negara-negara Eropa Barat. Banyaknya masyarakat miskin di Eropa Timur juga menjadi masalah meningkatnya migrasi ke Eropa Barat (Swiezak t.t.). Tidak semua negara Eropa Timur berhasil mengembangkan ekonominya, masih terdapat beberapa negara yang lemah dan bergantung secara ekonomi pada Rusia. Kondisi ini membuat kawasan Eropa Timur sangat rawan terhadap pengaruh dan kontrol Rusia (Buzan dan Waever 2003). Secara geografi Polandia termasuk negara Eropa Timur yang berada pada diantara Eropa Barat dan Eropa Timur. Sebelah barat berbatasan dengan Jerman, Timur dengan Belarusia dan Ukraina, Utara dengan enclave Rusia yaitu Kaliningrad dan selatan dengan Ceko dan Slovakia. Pada kawasan Eropa Timur, negara-negara didalamnya terbagi dalam sub regional, Polandia termasuk pada sub regional Eropa Tengah. Dilihat melalui kondisi geografisnya, Polandia terletak tepat diantara wilayah konflik yaitu Ukraina dan enclave Rusia yaitu Kaliningrad.

Kondisi geografi Polandia kemudian turut mempengaruhi elemen kedua yaitu amity dan enmity. Polandia, Ceko, Slovakia dan Hungaria tergabung dalam suatu asosiasi politik Visegard pada tahun 1993. Asosiasi ini dibentuk dengan tujuan menjalin kerjasama untuk mencapai common interest negara-negara di Eropa Tengah (Visegard Group t.t.). Polandia juga menjalin kerjasama dan hubungan dekat dengan negara-negara Eropa Barat, yaitu Perancis dan Jerman dalam Weimar Triangle. Tujuan dari terbentuknya Weimar Triangle adalah kerjasama dalam bidang politik, ekonomi dan sosial diantara Polandia, Jerman dan Perancis (Ministry of Foreign Affairs Republic of Poland t.t.). Bertetangga dengan negara-negara Eastern Borderlands seperti Belarusia dan Ukraina, Polandia berusaha untuk membantu mengembangkan demokrasi dan mengajak negara-negara tersebut untuk lebih dekat dengan Eropa Barat. Hal ini ditunjukkan Polandia dengan menjadi negara pertama yang mengakui kemerdekaan Ukraina (Missala t.t.). Pada tahun 1994, Polandia dan Ukraina menjalin suatu kerjasama yang disebut Polish-Ukraine Partnership. Hubungan dekat antara Polandia dan Ukraina bertujuan untuk memperkuat demokrasi dan mendukung Ukraina untuk dekat dengan negara-negara Barat (Missala t.t.). 
Terjalinnya kerjasama dengan negara-negara disekitarnya dapat membantu memperkuat kerjasama dalam menjaga keamanan regional. Kondisi geografis Polandia mempengaruhi keamanan wilayahnya pada krisis Ukraina 2014. Polandia berbatasan langsung dengan wilayah konflik yaitu Ukraina dan Kaliningrad yang menjadi pos militer Rusia. Menurut Barry buzan, ancaman lebih mudah berpindah atau merambat ke tempat berada dekat secara geografis (Buzan dan Waever, 2003). Sehingga adanya peristiwa krisis di Ukraina ini kemudian menjadi ancaman pula bagi wilayah Polandia. Pengaruh Rusia serta kepentingan Uni Eropa untuk membendung kekuatan Rusia, membuat kawasan Eropa Timur menjadi battleground. Disatu sisi Rusia masih menganggap kawasan ini sebagai sphere of influence dari kebijakan dan kepentingannya. Bagi Uni Eropa kawasan Eropa Timur sangat penting bagi keamanan Eropa, untuk itu Uni Eropa pun berusaha menarik negara-negara di kawasan Eropa Timur untuk bergabung dalam organisasi. Uni Eropa telah membentuk kebijakan khusus terkait kawasan Eropa Timur yaitu European Neighborhood Policy yang dibentuk pada tahun 2002, dan kemudian ditambahkan Eastern Partnership pada tahun 2009. Eastern Partnership bertujuan untuk memperbaiki integrasi dan mengembangkan hubungan kerjasama ekonomi antara Uni Eropa dan Eropa Timur (Smith, 2005).

Bagi negara-negara di kawasan Eropa Timur keberadaan negaranegara Eropa Barat membantu mereka dalam menstabilkan negaranya. Hal ini disebabkan masih lemahnya pemerintahan serta ekonomi negara-negara Eropa Timur. Hubungan kerjasama dengan negara-negara Eropa Barat dianggap penting dalam menjaga keamanan kawasan. Negara-negara di kawasan Eropa Timur sangat memperhatikan sikap, tindakan dan kebijakan yang dibentuk oleh Rusia. Rusia tidak memiliki masalah dalam hal keamanan negaranya, namun fokus keamanan regional Eropa Timur ada pada Rusia (Smith 2005). Sebagai kawasan yang berada diantara kekuatan besar, negara-negara Eropa Timur perlu memperhatikan bagaimana pengaruh Rusia sebagai regional power. Hal ini kemudian mempengaruhi bagaimana fokus kebijakan negara-negara di Eropa Timur mengarah pada keamanan wilayahnya dari pengaruh Rusia. Namun tidak semua negara-negara Eropa Timur kemudian berusaha untuk menjauh dari pengaruh Rusia. Belarusia, merupakan negara Eropa Timur yang justru ingin menjadi bagian Rusia dan menyerahkan kedaulatan negaranya (Smith 2005). 
Berakhirnya kekuasaan Uni Soviet kemudian membuat banyak negara Eropa Timur yang ingin memerdekakan diri dan lepas dari pegaruh komunisme. Hal ini kemudian menarik Polandia untuk kemudian mengajak dan memberikan pengaruh pada negara-negara Eropa Timur untuk dekat dengan Eropa Barat. Pada tahun 1990 Polandia membentuk kebijakan luar negeri yang mengedepankan integrasi dalam institusi internasional dan menormalisasi hubungan dengan negara-negara tetangga. Diawali dengan menjadi anggota dari Council of Europe pada tahun 1991, World Trade Organization (WTO) pada tahun 1995, dan Organization for Economic Cooperation and Development tahun 1996. Namun pencapaian paling baik yang dilakukan Polandia adalah bergabungnya dengan NATO pada tahun 1999 dan Uni Eropa pada tahun 2004 (Missala t.t.).

Setelah menjadi anggota Uni Eropa pada tahun 2004, kebijakan Polandia berfokus pada Eropa Timur serta isu-isu keamanan. Tahun 2008, Polandia menjadi pencetus Eastern Partnership dan mendapatkan persetujuan European Council. Tujuan dari Eastern Partnership adalah untuk membantu para negara yang terlibat untuk memenuhi kriteria menjadi anggota Uni Eropa. Selain itu Polandia juga menginisiasikan adanya European Endowment for Democracy pada tahun 2011, dengan tujuan untuk membantu negara-negara Eropa Timur untuk meningkatkan demokrasi di negaranya. Kedekatan antara Polandia dan Ukraina telah terjalin sejak terbentuknya Polish-Ukraine Partnership pada tahun 1994 (Missala t.t.). Polandia tidak setuju dengan sikap Rusia yang melakukan aneksasi terhadap Krimea. Perdana Menteri Polandia pada tahun 2014, Donald Tusk, mengungkapkan "We should be able to stop Russia in its aggresive more precisely in order to avoid a conflict" (Slowikowska 2014). Kondisi ini dipengaruhi juga dengan kebijakan keamanan Polandia, dimana kedaulatan dan keamanan negara-negara Eropa Timur sangat penting dan mempengaruhi keamanan wilayahnya. Donald Tusk juga menambahkan bahwa penting untuk mencegah aneksasi Rusia terhadap Krimea semakin luas dan menimbulkan konflik yang lebih besar di Eropa Timur (Slowikowska 2014).

Krisis Ukraina kemudian memicu negara-negara sekitarnya untuk semakin fokus dan waspada terhadap keamanan wilayahnya (Kakachia 2014). Moldova adalah salah satu negara yang terkena dampak krisis Ukraina. Kondisi geografi Moldova yang berbatasan 
langsung dengan Ukraina tentu merasakan dampak dari krisis. Kepentingan utama bagi Moldova adalah Ukraina tetap aman dan tidak jatuh dalam pengaruh Rusia meskipun jika akhirnya Krimea harus lepas dan menjadi bagian Rusia (Cebotari 2015). Moldova dan Ukraina dapat dikatakan sebagai satu blok wilayah, jika Ukraina mengalami gangguan maka dipastikan Moldova pun terkena dampak, begitu pula sebaliknya.

Polandia mengalami kondisi yang sama pada keamanan wilayahnya. Kekhawatiran Polandia bukan tanpa alasan, hal ini dikarenakan wilayah Polandia berbatasan langsung dengan Ukraina. Perdana Menteri Polandia tahun 2014, Donald Tusk, menyatakan bahwa kondisi geografi Polandia yang berbatasan langsung dengan Ukraina menjadi terancam apabila Rusia meningkatkan agresivitasnya (Slowikowska 2014). Satu-satunya yang menjadi pembatas antara Polandia dan Rusia adalah Ukraina, apabila Ukraina mengalami konflik maka Polandia pun turut terancam (Missala t.t.). Selain itu, Polandia juga berbatasan langsung dengan enclave milik Rusia yaitu Kaliningrad. Kaliningrad menjadi pos terdepan bagi militer Rusia. Dalam wilayah tersebut Rusia telah meletakkan radar dan sistem pertahanan udara serta anti-shipping missile untuk melawan serangan dari laut (BBC News 2016). Kondisi ini merupakan pertama kali dalam delapan tahun terakhir dimana Polandia merasa bahwa keamanannya terancam. Sebelumnya tidak ada permasalahan perbataasan, hubungan dengan negara tetangganya terjalin dengan baik, resiko mendapatkan serangan atau agresi juga sangat kecil.

Kekhawatiran Polandia juga didasari adanya warga negara Polandia yang tinggal di Ukraina. Sekitar 144.000 warga negara Polandia berada di Ukraina, krisis yang terjadi tentu dapat membahayakan keselamatan warganya (Ministry of Foreign Affairs Republic of Poland t.t.). Pada tahun 2014 Presiden Vladimir Putin mengeluarkan pernyataan, "If I wanted, in two days I could have Russian troops not only in Kiev, but also in Warsaw, Riga, Vilnus, Talinn and Bucharest"(Rettman 2014). Tidak hanya melalui pernyataan, ancaman dari Rusia semakin membuat Polandia khawatir karena pada 2016 Rusia kembali menempatkan air missile di Kaliningrad untuk melawan pertahanan misil Amerika Serikat dan NATO di Eropa Timur (Capelouto 2016). Meskipun belum ada serangan langsung dari Rusia yang mengancam wilayah Polandia, namun tindakan Rusia tersebut membuat Polandia terancam. Ketua Badan 
Keamanan Nasional Polandia, Stanislaw Koziej, menjelaskan, "It is true that today we are not threatened directly by an attack of foreign troops on our territory, but over a longer term we cannot exclude the possibility" (Kenney 2014). Untuk mengatasi keamanan negaranya, pada tahun 2014 Polandia mengeluarkan biaya 1,95 persen dari GDP untuk militer dan keamanan. Memasuki tahun 2016 ini Polandia telah merencanakan peningkatan biaya militer dan keamanannya hingga 2 persen dari GDP (Missala t.t.).

Menanggapi kondisi krisis di Ukraina dan dampaknya terhadap Polandia, Donald Tusk, Perdana Menteri Polandia pada tahun 2014, menegaskan bahwa Polandia harus menjaga, mendukung serta membantu Ukraina. Meskipun ancaman Rusia memang belum secara langsung masuk ke Polandia, namun kondisi yang tidak stabil di Ukraina dapat membuat keadaan keamanan Polandia semakin terancam (Britz et.al 2016). Tetapi hal tersebut tidak membuat Polandia kemudian mundur dalam mendukung sanksi terhadap Rusia. Menteri Luar Negeri Polandia tahun 2014, Radoslaw Sikorski, kemudian menambahkan bahwa sikap dan tindakan Rusia terhadap Krimea tidak bisa ditoleransi, baik Polandia dan dunia internasional perlu bersikap tegas terhadap Rusia. Menurut Donald Tusk, sikap Rusia tidak hanya membahayakan Krimea dan Ukraina saja namun dampaknya meluas pada negara-negara Eropa dan Atlantik (Britz et.al 2016).

Ewa Kopacz yang menjabat sebagai Perdana Menteri Polandia pada tahun 2015, tetap menunjukkan sikap waspada terhadap Rusia, dan terus berusaha meningkatkan kerjasama dalam mengatasi krisis Ukraina (Britz et.al 2016). Lebih lanjut, Ewa Kopacz juga menyatakan bahwa Polandia menjadi pendukung utama bagi Ukraina dalam Uni Eropa, dan Polandia berusaha meyakinkan negara-negara lain untuk membantu Ukraina. Menteri Luar negeri Polandia tahun 2015, Grzegorz Schetyna kemudian menambahkan bahwa krisis yang terjadi di Ukraina menjadi ancaman tidak hanya pada Polandia, namun juga stabilitas regional dan tatanan order dan keamanan Eropa. Ukraina menjadi kunci bagi keamanan Polandia serta keamanan di kawasan. Dukungan Polandia terhadap sanksi dan keamanan Ukraina merupakan reaksi yang paling tegas dibandingkan negara-negara lain di Eropa (Britz et.al 2016).

Secara geografis ancaman Rusia sangat mudah mengganggu 
keamanan wilayah Polandia (Simmons et.al 2015). Peningkatan aktifitas militer di Kaliningrad dan pernyataan ancaman dari Vladimir Putin jelas membuat Polandia cemas terhadap keamanan negaranya. Meskipun Polandia telah meningkatkan biaya belanja militer mencapai 2 persen dari GDP di tahun 2016, Polandia menghindari penggunaan kekuatan militer untuk melawan Rusia, karena hal tersebut memicu agresivitas Rusia. Menurut Menteri Luar Negeri Polandia tahun 2015, Grzegorz Schetyna, sanksi ekonomi adalah senjata yang tepat untuk digunakan melawan Rusia. Hal ini bertujuan mencegah sikap Rusia agar tidak semakin agresif, dan dikhawatirkan Rusia menggunakan kekuatan militernya di negaranegara Eropa Timur lainnya termasuk Polandia (Buras 2015).

Krisis yang terjadi di Ukraina telah mendatangkan dampak buruk bagi keamanan Polandia. Kondisi ini kemudian dapat dijelaskan dengan peringkat analisis security constellation yang pertama yaitu, dimana tingkat kerentanan suatu negara menentukan kehawatiran terhadap suatu ancaman (Buzan dan Waever 2003). Hal tersebut kemudian mempengaruhi persepsi terhadap negara atau kelompok negara lain sebagai ancaman meskipun belum ada ancaman secara langsung. Melihat bagaimana kondisi geografi Polandia yang berbatasan dengan wilayah konflik yaitu Ukraina dan Kaliningrad kemudian membuat Polandia secara tidak langsung terkena dampak dari krisis. Hal ini menunjukkan bahwa kondisi regional security complex Eropa Timur rentan terhadap keamanan negaranegara didalamnya. Polandia rentan terhadap ancaman keamanan wilayahnya saat krisis Ukraina terjadi. Tidak hanya dipengaruhi oleh kondisi geografi yang berdekatan saja namun juga adanya pernyataan Vladimir Putin yang dapat dikatakan ancaman bagi Polandia meskipun belum terlaksana. Kerentanan Polandia dalam krisis Ukraina ini menyebabkan Polandia harus tetap bertindak tegas dalam mencegah tindakan-tindakan agresif Rusia. Dengan tetap tegas mendukung sanksi ekonomi terhadap Rusia, dapat mencegah tindakan Rusia agar tidak semakin meluas ke negara lain di Eropa Timur.

\section{Dampak Keamanan Kawasan Terhadap Ekonomi Polandia}

Mengarah pada penjelasan Alberto Ades dan Hak B. Chua (1997) bahwa dampak keamanan regional terhadap ekonomi adalah 
terganggunya arus perdagangan. Kondisi perdagangan produk pangan Polandia akibat terjadi Krisis Ukraina dan embargo Rusia memburuk. Tahun 2014 menjadi tahun yang cukup merugikan bagi perdagangan produk pangan Polandia. Menurut data dari Menteri Pertanian Polandia, pada tahun 2013 sebanyak 804.000 ton buah dan sayur dengan nilai sekitar 336 juta euro diekspor ke Rusia. Pada tahun yang sama, 56 persen atau sebanyak 677.000 ton apel diekspor ke Rusia. Namun setelah Rusia memberlakukan embargo terhadap produk pangan dari Uni Eropa di tahun 2014, Polandia mengalami kerugian mencapai 500 juta euro (Atradius Dutch State Business 2014). Seorang pemilik perkebunan apel di Polandia bernama Anna Staszewska menyatakan, bahwa situasi pasar penjualan apel Polandia sedang mengalami kesulitan akibat embargo dari Rusia (Foy dan Wasik 2016). Meskipun Uni Eropa telah memberikan bantuan dana untuk mengatasi dampak embargo sebesar 125 juta euro, tetapi menurut Marek Sawicki, jumlah tersebut masih belum bisa menutupi kerugian akibat embargo Rusia (The Economist 2014).

Sebagai solusi untuk mengatasi adanya hambatan perdagangan, maka Polandia mencari alternatif pasar untuk menjual produksi apelnya. Untuk itu Polandia kemudian mencoba menjual apelnya melalui Belarusia. Namun sayangnya rencana ini tidak bertahan lama, kerena sejak 2016 Rusia telah memperketat pengawasan terhadap impor produk makanan dari Belarusia. Akibatnya, pada Mei 2016 sebanyak 19.5 ton apel dari Polandia yang dikirim melalui Belarusia dihancurkan di sekitar perbatasan antara Belarusia dan Rusia (Harper 2016).

Selain arus perdagangan, dampak lain yang diterima Polandia adalah arus suplai energi dari Rusia juga terhambat. Pada Februari tahun 2014 Rusia menaikkan harga gas untuk Ukraina setelah turunnya Yanukovich sebagai presiden Ukraina. Kemudian akibat konflik yang terjadi antara Rusia dan Ukraina, Rusia mengurangi suplai gas ke Ukraina pada Juni 2014 (BBC News 2015). Kondisi tersebut membuat Ukraina tidak mampu membayar suplai gas yang dibutuhkan. Disampaikan oleh CEO Gazprom, Alexei Miller, bahwa Gazprom tidak mengirimkan gas ke Ukraina sebelum Ukraina mampu membayar gas (BBC News 2015). Menanggapi tindakan Rusia yang memotong suplai gas ke Ukraina, Polandia kemudian membentuk perjanjian kerjasama reverse-flow gas dengan Ukraina untuk membantu memberikan suplai gas kepada Ukraina. Tetapi 
tindakan Polandia ini kemudian memicu Rusia untuk membatasi arus suplai gas ke Polandia. Perusahaan kontrol gas dan minyak Polandia, Polskie Gornictwo Naftowe i Gazownictwo (PGNiG), mengungkapkan bahwa suplai gas dari Rusia menurun hingga 20 sampai 24 persen pada September 2014.

Gambar 3.1 Produksi Industri Polandia

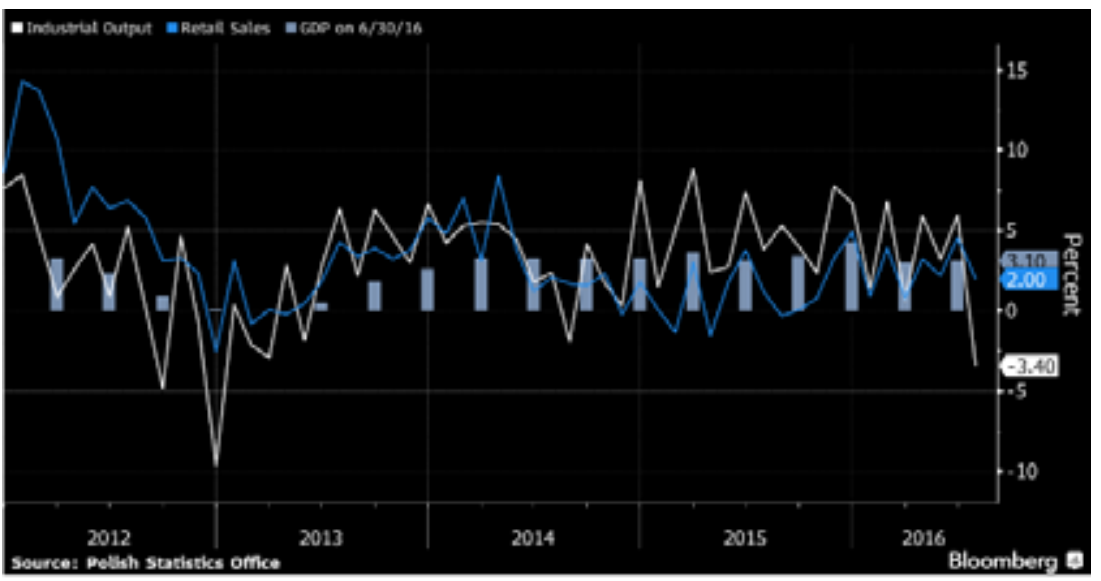

(Sumber: Dorota Bartyzel, No Escape From 3\% Growth After Dismal Flop for Polish Economy 2016)

Menurunnya suplai gas yang diterima Polandia dari Rusia mengakibatkan menurunnya produktititas pada industrinya (lihat pada gambar 3.1). Pemotongan suplai gas dari Rusia pada tahun 2014 kemudian mengakibatkan menurunnya produksi industrinya, ditunjukkan dengan grafik garis putih yang menurun di tahun 2014. Untuk mengatasi suplai gasnya Polandia kemudian menambah pembelian gas dari negara-negara lain di Eropa. Pada 2014 Polandia membeli dan menjalin kontrak untuk melakukan pengiriman gas dari Ceko sebanyak 2 miliar meter kubik per tahun. Selain itu Polandia juga membeli gas dari Jerman sebanyak 600 juta meter kubik (Strzelecki dan Martewicz 2014).

Selain pada hambatan pergadangan dan suplai energi, keamanan regional berdampak pada meningkatnya belanja militer negara. Sebelum krisis terjadi, pada tahun 2012 Polandia memiliki rencana untuk meningkatkan militernya sebesar 25 miliar dolar, namun jumlah tersebut rupanya bertambah seiring meningkatnya ancaman (Bach 2015). Kekhawatiran Polandia terhadap agresi Rusia, kemudian membuat Polandia merencanakan pembangunan sistem 
pertahanan jangka panjang dalam rentang waktu 2013 sampai 2022. Pembangunan tersebut antara lain meliputi, menambah jumlah helikopter, kapal selam dan perlengkapan militer lainnya yang mencapai biaya sebesar 40 miliar euro (Nougayrede 2015). Sejak terjadinya krisis Ukraina pada tahun 2014 pemerintahan Polandia meningkatkan kapabilitas militernya dan kewaspadaan terhadap Rusia. Kekhawatiran Polandia salah satunya didasari oleh adanya persepsi bahwa Polandia berdiri sendiri di wilayah Eropa Timur. Persepsi tersebut muncul karena negara-negara Baltik yang memiliki perspektif yang sejalan dengan Polandia nyatanya tidak dapat menahan penetrasi pengaruh Rusia. Hungaria dilihat oleh Polandia sebagai client-state Rusia, Ceko dan Slovakia dipandang tidak dapat menahan masuknya arus kapital dan pengaruh Rusia yang menurut Polandia, dibuktikan dengan kritik dan perlawanan mereka terhadap sanksi ekonomi yang diberikan Uni Eropa terhadap Rusia (Nougayrede 2015). Peningkatan dalam sektor militer merupakan hal terpenting saat ini, mengingat kondisi geografis Polandia yang dekat dengan wilayah konflik (Bach 2015). Pada awal tahun 2014 Polandia mengeluarkan biaya 1,95 persen dari GDP atau sebesar 4.7 miliar dolar untuk belanja militer dan keamanan (Lyman 2014). Ewa Kopacz, selaku Perdana Menteri Polandia tahun 2015 menyatakan, memasuki tahun 2016 ini Polandia telah merencanakan peningkatan biaya militer dan keamanannya hingga 2 persen dari GDP (Missala t.t.). Hal tersebut ditunjukkan dengan pengeluaran Polandia dalam sektor keamanannya yang meningkat sebesar 10.5 miliar dolar dalam rentang waktu tahun 2014 hingga 2016 (Collins 2016).

Selain itu, Polandia juga mempersiapkan tujuh puluh helikopter militer dan tiga puluh diantaranya merupakan helikopter penyerang, dengan biaya 2.5 miliar dolar yang digunakan untuk mengawasi wilayah perbatasan (Croft 2014). Menteri Pertahanan Polandia, Tomasz Siemonak, menjelaskan bahwa Polandia meningkatkan jumlah pasukan militernya. Sejak Mei 2014, telah tercatat 10.000 orang sukarelawan yang menerima pelatihan militer. Jumlah ini terus bertambah hingga 2016 tercatat 15.000 sukarelawan (Bach 2015). Pada tahun 2015 Polandia membangun enam menara pengawas dengan ketinggian mencapai lima puluh meter untuk mengawasi wilayah perbatasan Kaliningrad. Untuk membangun menara ini, menghabiskan biaya yang cukup besar, estimasi biaya mencapai 14 juta zloty atau setara dengan 3.7 juta euro. Meskipun tidak seluruhnya dikeluarkan oleh Polandia, 75 persen dari biaya 
tersebut mendapatkan bantuan dari Uni Eropa, dan sisanya tetap ditanggung oleh Polandia (Bach 2015). Bantuan dari Uni Eropa tersebut menunjukkan bahwa kerugian yang diterima Polandia akibat adanya krisis masih mendapatkan bantuan dari Uni Eropa. Dampak lain yang ditimbulkan dari adanya krisis Ukraina adalah masuknya pengungsi atau refugee dari Ukraina di Polandia. Tahun 2013 jumlah permohonan masuk dari Ukraina ke Polandia berkisar 1.060 jiwa. Pada tahun 2014, jumlah permohonan refugee meningkat hingga 14.040 jiwa.

Gambar 3.2. Hasil Survei Polish Public Opinion Center Tahun 2016

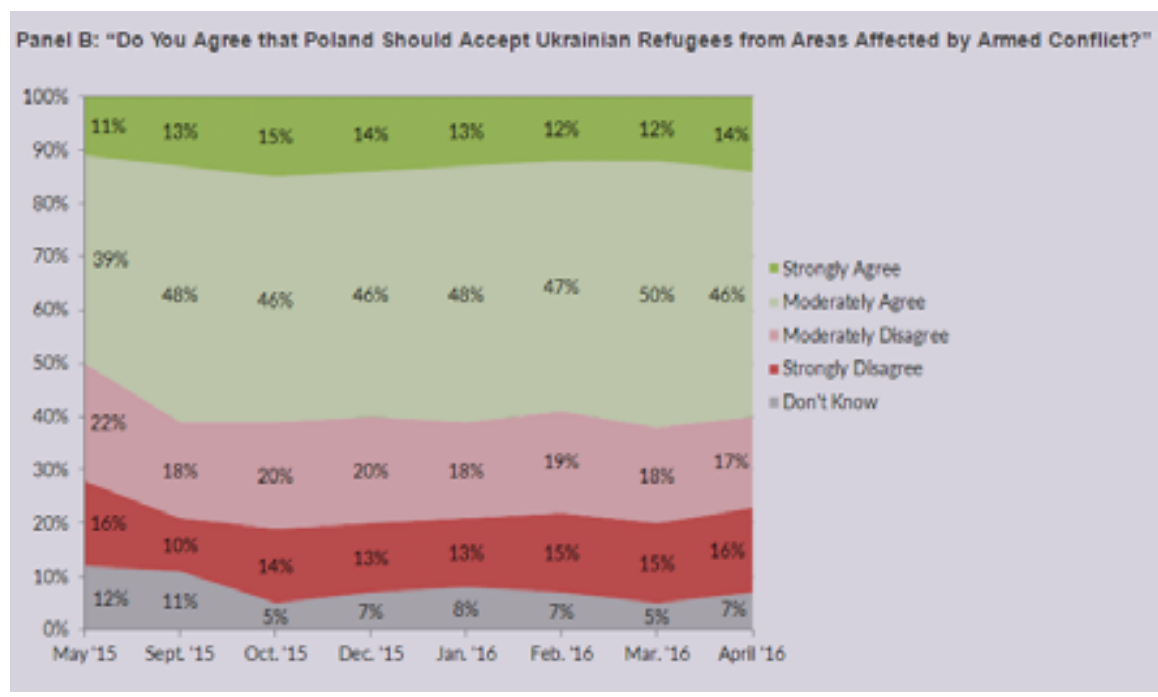

(Sumber: Bart Bachman. Diminishing Solidarity: Polish Attitudes Toward The European Migration and Refugee Crisis 2016)

Namun dukungan Polandia terhadap Ukraina dengan menerima refugee dari Ukraina mendapatkan protes dari masyarakat Polandia. Dilansir dari data survei Polish Public Opinion Center pada tahun 2015, menunjukkan respon masyarakat Polandia terhadap meningkatnya refugee Ukraina di Polandia (lihat gambar 3.2). Pada data tersebut menunjukkan bahwa tidak seluruh masyarakat Polandia setuju terhadap masuknya refugee dari Ukraina. Menurut hasil survei, pada Januari 2016 tercatat 13 persen masyarakat Polandia tidak setuju dengan masuknya refugee dari Ukraina, jumlah ini bertambah pada April 2016 mencapai 16 persen. Respon masyarakat Polandia yang tidak setuju didasari beberapa alasan, 
diantaranya: (1) kondisi ekonomi mengenai distribusi kebutuhan dan penggunaan infrastruktur; (2) kekhawatiran terhadap meningkatnya kriminalitas (Bachman 2016). Selain kedua alasan tersebut, muncul pula kekhawatiran menyebarnya virus atau penyakit yang terbawa oleh refugee. Presiden Partai Law and Justice, Jaroslaw Kaczynski, menyatakan bahwa refugee yang masuk bisa saja membawa berbagai macam virus, parasit, protozoa dan berbagai penyakit lainnya yang membahayakan keselamatan masyarakat Polandia (Bachman 2016).

\section{Kesimpulan}

Melalui penjelasan diatas, maka dapat disimpulkan bahwa dua hipotesis pada penelitian kebijakan Polandia dalam mendukung sanksi ekonomi telah terbukti. Primary objectives Polandia dalam mendukung sanksi adalah untuk menjaga keamanan Eropa Timur yang berpengaruh pada keamanan wilayahnya. Sanksi ekonomi diberikan dengan tujuan menekan ekonomi Rusia agar tidak dapat melakukan tindakan yang lebih agresif dan mengancam Eropa Timur lebih luas lagi. Kemudian pada secondary objectives menyangkut pada kondisi keamanan negara menentukan kondisi ekonominya juga. Ketika Polandia mengalami ancaman keamanan maka prioritas negara adalah melindungi wilayah kedaulatannya. Hal ini ditunjukkan dengan meningkatnya biaya bagi pegamanan dan militer. Selain itu kondisi krisis Ukraina juga mengahambat arus perdagangan dan suplai gas kepada Polandia.

Dengan demikian, berdasarkan pembahasan tersebut dapat disimpulkan bahwa dukungan Polandia terhadap sanksi Uni Eropa kepada Rusia memang bertujuan untuk mengamankan kawasan Eropa Timur. Sikap agresif Rusia membahayakan negara-negara di Eropa Timur, tidak hanya Ukraina namun negara lain disekitarnya pun terkena dampak. Selain itu dampak dari terancamnya keamanan wilayah negara berdampak pula pada ekonomi. Hambatan terhadap arus perdagangan serta suplai energi memberikan kerugian bagi negara. Meningkatnya jumlah belanja militer serta refugee juga menjadi masalah bagi negara. Oleh karena itu Polandia tetap mendukung sanksi ekonomi terhadap Rusia agar Rusia tidak lagi mengancam kawasan Eropa Timur, serta dapat menjaga keamanan wilayah negaranya dan perekonomiannya. 


\section{Referensi}

A.C, 2014. Eat Apples to Annoy Putin. [Online] Tersedia di: http://www.economist.com/blogs/ easternapproaches/2014/08/poland-and-russia [Diakses 15 September 2015].

Acharya, A. \& Johnston, A. I., t.thn. Comparing Regional Institutions: An Introduction. Cambridge University Press.

Ades, A. \& Chua, H. B., 1997. Thy Neighbor's Curse: Regional Instability And Economic Growth. Journal of Economic Growth.

Atradius Dutch State Business, 2014. Market MonitorFocus On The Food Industry-Poland. [Online] Tersedia di: https://atradiusdutchstatebusiness.nl/nl/ publikaties/market-monitor---focus-on-the-food-industry--poland-.html [Diakses 20 Desember 2016].

Bachman, B., 2016. Diminishing Solidarity: Polish Attitudes Towards The European Migration and Refugees Crisis. [Online] Tersedia di: http://www.migrationpolicy.org/article/ diminishing-solidarity-polish-attitudes-toward-europeanmigration-and-refugee-crisis [Diakses 17 Desember 2016].

Bach, S., 2015. Poland Increases Military Spending. [Online] Tersedia di: https://www.wsws.org/en/articles/2015/02/25/ pola-f25.html[Diakses 17 Desember 2016].

Barber, J., 1944. Economic Sanctions As A Policy Instrument. Royal Institute of International Affairs.

BBC News, 2015. Russia Halt Gas Supplies To Ukraine After Talks Breakdown. [Online] Tersedia di: http://www.bbc.com/news/worldeurope-33341322 [Diakses 17 Desember 2016].

BBC News, 2016. Kaliningrad: New Russian Missile Deployment Angers NATO. [Online] Tersedia di: http://www.bbc.com/news/worldeurope-38070201 [Diakses 6 Desember 2016].

BBC News, 2016. Ukraine Crisis: What's Going on In Crimea. [Online] Tersedia di: http://www.bbc.com/news/worldeurope-25182823 [Diakses 15 September 2016].

Britz, M., 2016. Developments in Security Policy: European and US Considerations Regarding The War in Ukraine. Swedish Defence University. 
Buras, P., 2015. View From Warsaw: Sanctions Are The EU's Only Tool. [Online] Tersedia di: http://www.ecfr.eu/article/commentary_ sanctions_are_the_eus_only_tool311339 [Diakses 7 Desember 2016].

Buzan, Barry, dan Ole Waever. 2003. Regions and Power. Cambridge Studies in International Relations.

Cebotari, S., 2015. The Repercussion of Russian And Ukrainian Conflict on Security of The Republic Moldova. Journal of Social Science.

CEE Identity, t.thn. Ukraine Crisis and The Hungarian National Interest. [Online] Tersedia di: http://www.ceeidentity.eu/news/ukraine-crisis [Diakses 6 Desember 2016].

Coffey, L., 2016. Europe must Remain Firm on Sanction Against Russia. [Online] Tersedia di: http://www.aljazeera.com/indepth/ opinion / 2016/07/europe-remain-firm-sanctionsrussia-160710065419257.html [Diakses 10 Desember 2016].

Collins, R., 2016. Russian Threat Prompts Military Spending Surge in Central Europe. [Online] Tersedia di: http://www.politico.eu/article/militaryspending-surge-central-europe-russia-threat-ukraine-conflictdefense-budgets/ [Diakses 15 Desember 2016].

Croft, A., 2014. Ukraine Crisis Forces European Defense Spending Rethink. [Online] Tersedia di: http:/ / www.reuters.com/article/us-nato-summitspending-idUSKBN0GR1EB20140827 [Diakses 15 Desember 2016].

Dimitrov, T., t.thn. Fundamentals of Economic Stability And Security in Central And Eastern Europe. Institute For Advance Studies.

Dingsdale, A., 1999. Redifining Eastern Europe: A New Regional Geography of Post-Socialist Europe. Geographical Association.

Early, B., 2016. Statecraft And The Limitations of Economic Sanction. E-International Relation.

Easton, A., 2015. Russian Apples Ban Triggers Export Rethink for Polish Farmer. [Online] Tersedia di: https://next.ft.com/content/fe848682-2fbc-11e591ac-a5e17d9b4cff [Diakses 15 September 2015]. 
Euractiv, 2016. Germany, Austria Favour Gradual Phasing Out Russia Sanction. [Online] Tersedia di: http://www.euractiv.com/section/global-europe/ news/germany-austria-favour-gradual-phasing-out-of-russiasanctions/ [Diakses 10 Desember 2016].

European Comission, t.thn. Financial Programming and Budget: Polandia. [Online] Tersedia di: http://ec.europa.eu/budget/mycountry/PL/ index_en.cfm\#cinfo [Diakses 25 Maret 2016].

European Council, 2014. EU Restrictive Measures in REsponse To The Crisis in Ukraine. [Online] Tersedia di: http://www.consilium.europa.eu/en/policies/ sanctions/ukraine-crisis/ [Diakses 14 Maret 2016].

European Council, t.thn. Timeline-EU Restrictive Measures in Response to The Crisis in Ukraine. [Online] Tersedia di: http://www.consilium.europa.eu/en/policies/ sanctions/ukraine-crisis/history-ukraine-crisis/ [Diakses 14 Maret 2016].

Foy, H. \& Wasik, Z., 2016. Polish Apple Farmers Bear Brunt of EU-Russia Economic War. [Online] Tersedia di: https:/ / www.ft.com/content/a8128350-6844-11e6a0b1-d87a9fea034f [Diakses 15 Desember 2016].

Gotev, G., 2016. France Wants EU Summit To Discuss Russia Sanction. [Online] Tersedia di: http://www.euractiv.com/section/global-europe/ news / france-wants-eu-summit-to-discuss-russia-sanctions / [Diakses 18 September 2016].

Harper, J., 2016. Polish Apples Feel the Crunch. [Online] Tersedia di: http://www.dw.com/en/polish-apples-feel-thecrunch/a-19294384 [Diakses 15 Desember 2016].

ING Group, 2014. Russian Sanction: 130.000 European Jobs at Stake. ING Group: International Trade Special.

Jancarikova, T. \& Muller, R., 2016. EU Should Drop Russia Sanctions, Slovak PM Says After Meeting Putin. [Online] Tersedia di: http://www.reuters.com/article/us-ukrainecrisis-slovakia-idUSKCN1111A1 [Diakses 15 Desember 2016].

Kakachia, K., 2014. The Ukraine Crisis: Repercussion On Georgia. Caucasus Analytical Digest.

Kenney, P., 2014. Why Poland Cares So Much About Ukraine. [Online] 
Tersedia di: https://www.nytimes.com/2014/03/10/opinion/ why-poland-cares-so-much-about-ukraine.html [Diakses 5 Desember 2016].

Kraatz, S., 2014. The Russian Embargo: Impact on The Economic and Employment Situation in The EU. Policy Departement A: Economy Scientific Policy European Parliament.

Luxmoore, M., 2015. In Poland Challenge to Integrate 'Invisible' Ukrainian Refugees. [Online] Tersedia di: http:/ / america.aljazeera.com/articles/2015/8/23/ poland-integrates-invisible-refugees-east-ukraine.html [Diakses 17 Desember 2016].

Lyman, R., 2014. Across Eastern Europe, Military Spending Lags. [Online] Tersedia di: https://www.nytimes.com/2014/09/06/world/ europe/in-eastern-europe-ukraine-crisis-focuses-minds-onnato-and-military-spending.html?_r=0 [Diakses 17 Desember 2016].

Lyman, R., 2015. Ukrainian Migrants Fleeing Conflict Get a Cool Reception in Europe. [Online] Tersedia di: http://www.nytimes.com/2015/05/31/world/ europe/ukrainian-migrants-fleeing-conflict-get-a-coolreception-in-europe.html [Diakses 17 Desember 2016].

Michalopoulos, S., 2016. Russia Extends Embargo on EU Food Products. [Online] Tersedia di: http://www.euractiv.com/section/agriculturefood/news/russia-extends-embargo-on-eu-food-products/ [Diakses 15 Maret 2016].

Ministry of Foreign Affairs Republic of Poland, t.thn.Ukraine.[Online] Tersedia di: http://www.msz.gov.pl/en/foreign_policy/ eastern_policy / ukraine;jsessionid=FB2BB2E37CD039536BA9D 15DAEFD05A6.cmsap5p [Diakses 6 Desember 2016].

Ministry of Foreign Affairs Republic of Poland, t.thn. Weimar Triangle. [Online] Tersedia di: http://www.msz.gov.pl/en/foreign_policy/ europe/wweimar_triangle1/weimar_triangle[Diakses Desember 2016].

Missala, A. B., 2016. Poland's Foreign and Security Policy: Main Directions. University of Warsaw.

Nougayrede, N., 2015. Polands Warning to Europe: Russia's Aggresion in Ukraine Changes Everything. [Online] 
Tersedia di: https://www.theguardian.com/ commentisfree/2015/apr/10/poland-warning-europerussia-aggression-ukraine-smolensk-plane-crash [Diakses 17 Desember 2016].

Press TV, 2016. EU Should End Economic BAns Against Russia: French President. [Online] Tersedia di: http://presstv.ir/Detail/2016/08/31/482471/ France-Hollande-Russia-Sanctions [Diakses 25 November 2016].

Press TV, 2016. French MPs Vote in Favor of Lifting EU Bans on Russia. [Online] Tersedia di: http://www.presstv.ir/ Detail/2016/04/29/463094/Russia-sanctions-France-lift-EU [Diakses 25 November 2016].

Radio Free Europe, 2015. Czech PM: Important to Keep Sanctions on Russia. [Online] Tersedia di: http://www.rferl.org/a/czech-pm-russiansanctions-pressure-important/27102900.html [Diakses 10 Desember 2016].

Radio Poland, 2014. Schetyna Backs EU Sanction Extensions Against Rusia. [Online] Tersedia di: http://www.thenews.pl/1/10/ Artykul/211080,Schetyna-backs-EU-sanctions-extensionagainst-Russia\#sthash.w5FEadI0.dpuf [Diakses 25 September 2015].

Radio Poland, 2014. Ukraine Crisis Creating 'Worst Case Scenario' for Polish Economy. [Online] Tersedia di: http://www.thenews.pl/1/12/ Artykul/164006,Ukraine-crisis-creating-worst-case-scenariofor-Polish-economy [Diakses 15 September 2015].

Rettman, A., 2014. Could Putin's Troops Be In Warsaw in Two Days. [Online] Tersedia di: https://euobserver.com/foreign/125807 [Diakses 6 Desember 2016].

RT News, 2014. Poland Stops Reverse Gas Flow to Ukraine, Kiev Blames Russia. [Online] Tersedia di: https://www.rt.com/business/186792-ukrainepoland-gas-reverse/ [Diakses 15 September 2015].

Sadecki, A., 2014. Hungary's Stance On The Ukrainian-Russian Conflict. [Online] Tersedia di: https://www.osw.waw.pl/en/publikacje/ 
analyses / 2014-05-21/ hungarys-stance-ukrainian-russianconflict [Diakses 10 Desember 2016].

Simmons, K., 2015. NATO Publics Blame Russia For Ukrainian Crisis But Reluctant to Provide Military Aid. [Online] Tersedia di: http://www.pewglobal.org/2015/06/10/natopublics-blame-russia-for-ukrainian-crisis-but-reluctant-toprovide-military-aid/ [Diakses 7 Desember 2016].

Slowikowska, K., 2014. Poland's Tusk Says Must Stop Crimea Crisis Expanding to Regional Conflict. [Online] Tersedia di: http://www.reuters.com/article/us-ukrainecrisis-poland-idUSBREA210KY20140302 [Diakses 6 Desember 2016].

Smith, K. E., 2005. The Outsiders: The European Neighbourhood Policy. International Affairs.

Strzelecki, M. \& Martewicz, M., 2014. Gazprom Limits Polish Gas Supplies as Reverse Flows Halt. [Online] Tersedia di: http://www.bloomberg.com/news/ articles/2014-09-10/ poland-says-gazprom-cut-gas-suppliesvia-belarus-ukraine [Diakses 15 September 2015].

Strzelecki, M. \& Martewicz, M., 2014. Gazprom Limits Polish Gas Supplies as Reverse Flows Halt. [Online] Tersedia di: https://www.bloomberg.com/news/ articles/2014-09-10/ poland-says-gazprom-cut-gas-suppliesvia-belarus-ukraine [Diakses 20 Desember 2016].

Swiezak, P., t.thn. International Challenges for Regional Security in Central and Eastern Europe-Poland. Departement of Strategic Analyses National Security Bureau.

Szary, W. \& Sobczak, P., 2016. Poland Says Lifting Russia Sanctions Now Would Weaken EU Authority. [Online] Tersedia di: http://www.reuters.com/article/us-ukrainecrisis-russia-poland-idUSKCNOYM1OS [Diakses 15 Desember 2016].

The Economist, 2014. Poland and Russia: Eat Apples To Annoy Putin. [Online] Tersedia di: http://www.economist.com/blogs/ easternapproaches/2014/08/poland-and-russia [Diakses 15 Desember 2016].

Times, T. F., 2014. EU Considers Effect of More Russian Sanctions. [Online] Tersedia di: http://www.ft.com/intl/cms/s/0/d64996a0- 
ae01-11e3-974d-00144feab7de.html\#axzz43SYrIcbs [Diakses 15 September 2015].

Trading Economics, 2016. Poland: Employment Rate. [Online] Tersedia di: http://www.tradingeconomics.com/poland/ unemployment-rate [Diakses 21 Maret 2016].

Visegard Group, t.thn. About The Visegard Group. [Online] Tersedia di: http://www.visegradgroup.eu/about [Diakses 5 Desember 2016].

Zbytniewska, K., 2016. A Very Polish NATO. [Online] Tersedia di: http://www.euractiv.com/section/global-europe/ news/a-very-polish-nato-summit/ [Diakses 25 November 2016]. 